\title{
The Implementation of Communicative Language Teaching by Iraqi English language Teachers
}

\author{
Arkhawan Fattah, Aminabibi Saidalvi
}

\begin{abstract}
The implementation of Communicative Language Teaching (CLT) has been debated by many researchers in the field of language teaching methodology. Much is done in this regard and literature confirms that the implementation of CLT in teaching English as a foreign language is challenging. Even though there are studies investigating the issue in Iraqi schools, little has been done in exploring the classroom practices of Communicative Language Teaching by the teachers. Thus, this study hopes to investigate how Iraqi English language teachers implement CLT in their classrooms. A qualitative method is used to collect data through classroom observation of 3 in-service English language teachers. The research question that is addressed is (to what extent the classroom practices of Iraqi English language teachers comply with the principles of Communicative Language Teaching?). The data collected from the observations are analyzed based on a checklist to compare them to the basic principles of communicative approach. The results of the study show that Iraqi English language teachers do not fully implement communicative approach in their classroom practices and their teachings mostly focus on grammar and vocabulary rather than meaningful communication. The results from this study will contribute to the field of knowledge about Communicative Language Teaching, particularly in Iraqi public schools. The outcome of this study will support teachers to overcome the current challenges in language teaching and provide better recommendation for them to improve their teaching and implementation of CLT approach.
\end{abstract}

Keywords: Classroom Practices, Communicative language Teaching, Iraqi EFL Classrooms.

\section{INTRODUCTION}

The need for a good command in English language for both communication and written purposes brings up the demand for adopting the best methodology in teaching English language primarily for communicative purposes. This is an issue in language teaching where the researchers and educators have to work on bridging the gap between the theoretical understanding of the language teaching methods and approaches and the language teachers' classroom practices.

Teachers' choice of language teaching approaches, methods and their classroom practices are studied by researchers and language educators [1]-[2]-[3]-[4]. The variation in teaching context influences the choice of

Revised Version Manuscript Received on April 19, 2019.

A.Fattah, School of Education, Faculty of Social Sciences and Humanities, Universiti Teknologi Malaysia, Skudai, Johor, Malaysia

A.Saidalvi, Language Academy, Faculty of Social Sciences and Humanities, Universiti Teknologi Malaysia, Skudai, Johor, Malaysia. Email: aminabibi@utm.my

language teaching methods. In this regard [5] indicated that there is no best method for everyone, it is the context that influences and decides the proper method. From [5]'s point of view a method is not good or bad in any objective sense, but has more or less pedagogic power to influence teachers' subjective understanding of their teaching. Thus, teachers choose their methods of teaching regardless of what proponents of one method or another prescribed for them to follow and teachers' classroom practices are observed to reflect the theoretical implications of various methods and approaches.

Many researchers [6]-[7]-[8] believe that integration of teachers' theoretical knowledge into classroom practices is necessary to enhance teachers' awareness of pedagogical options in language teaching. [9] believes that the knowledge of the subject matter is not enough to ensure teachers' good classroom practices but this knowledge must come with the practical skills needed for classroom instructions. He also indicated that the content knowledge for English language teachers is much more to being an English teacher than knowing English. Teachers need to elevate their skills with theoretical understanding of teaching methods and approaches and to be well aware of their context, especially in the case of teaching English as a foreign language.

Researchers raise issues on which teaching approach or method should be employed in language classroom practices, how the use of such approaches and methods affect language teaching and what challenges can emerge in language teaching due to following certain approaches or methods. Researchers [5]-[10] question if these approaches can be applied to another context that language is taught as a second or a foreign language. This issue signals that embedding a new approach without careful consideration of certain factors is a complex matter and more information is needed to understand language teaching practices in such contexts.

Researches on classroom practices of English language teachers both from the actual classroom environment and the viewpoint of the teachers can provide researchers with more solid evidences on the nature of teaching English language teachers' classroom practices regarding their theoretical understanding and implementation of different approaches and in their classrooms. Such researches can tell how their theoretical understanding and knowledge can reflect in their 
classroom practices, as well as the factors that can influence such practices. A qualitative study regarding classroom practices of the principles and characteristics of Communicative Language Teaching in English language classrooms can provide researchers and educators with information to bridge this gap between language teaching in theory and in practices and to make a comparison between what teachers know and say and what they practice in their teaching.

\section{BACKGROUND OF THE STUDY}

The growing need for good communication skills in English language has created a huge demand for English teaching around the world. In the $21 \mathrm{st}$ century Communicative Approach became the buzzword and dominant approach [11]-[12] that many countries adopted this approach in their English language textbooks. Communicative Language Teaching (CLT) is mostly described as an approach [2]. CLT have become a revolutionary, dominant paradigm in English language teaching in the west [13]-[14], where many Arab countries started to adopt and move toward implementing communicative language teaching [15] in teaching English as a Foreign language. Despite the rich theoretical foundation of the approach, there are still challenges in its practical implementation in English language classrooms.

Advocate Researchers [16]-[17]-[2]-[18] refer to this approach as both processes and goals in classroom learning. The main goal of CLT is to promote Communicative Competence of the learners. Due to the high demand on learning English and internationalization of the language the approach is widely adopted by many countries around the world to substitute the traditional methods and provide learners with more opportunities to learn languages.

According to [18], an approach can be understood as a set of principles about the goals of language teaching. According to this approach the goal of language teaching is to improve communicative competence of the learners to establish a meaningful communication in the target language [2]-[3]. To achieve this goal teachers are required to focus on communication in language classroom through interaction and the practice of real life situations. This was the reason that researchers started to speak in favor of Communicative approach. One more reason for this support is the inability of traditional methods in achieving language teaching goals. [19] indicate that traditional methods for teaching English as a second or a foreign language in many countries, especially in developing countries have yet to be successful enough to boost learners' communicative competence in English language. In contrast to other methods, [3] and [2] believe that Communicative Language Teaching provides language learners with many opportunities to use target language in different contexts and for various purposes.

[2] define Communicative language teaching as an Approach and identified five main principles. These principle are: learners learn a language through using it for communication, the goal of classroom activities should be authentic and meaningful, though accuracy is important but fluency is also a very important dimension in language

learning, communication does not only include oral communication but it is the integration of different language skills, and learning is a process of creative construction that involves trial and error. Teachers' understanding of these principles is crucial in their integration of classroom practices with their view on language teaching as theory.

[20] indicates that CLT is not implemented in reality as it is in the theory. This means there is a gap between theoretical knowledge on CLT and the practical implication of the approach in the classroom level. This could be one reason why English language teachers in many countries still follow the traditional teaching methods. [21] states that those teachers who do not have a complete understanding of CLT can hardly develop their practices appropriate to the learning context, and as a consequence of that they return to traditional teaching. The solution for this, as [22] suggests, is through pre-service or in-service training for language teachers about what CLT really is and how it can work in classroom environments. Therefore, the in-service training on CLT can reduce this gap and facilitate the teaching process to transform the classroom from teacher-centered classrooms to a more student-centered one.

According to [23], the implementation of communicative methodology is not an easy task, because in the communicative classroom students ultimately have to use the language productively and receptively, in unrehearsed contexts [24]. However, the need for a research on this issue is necessary to understand teachers' classroom practices. Furthermore, such a research can help teachers to make a better use of CLT principles in their classrooms more often.

Though adopting such an approach and transition from the traditional methods to implication of Communicative Language Teaching was not a hard task but there is still a big issue that requires extensive studies which is the gap between theoretical aspects of CLT as an approach in teaching languages and the implication of the approach on the classroom level. This sudden transformation from the traditional teaching methodology to the adaptation of the current approach without preparing the teachers and training them on the suitability and practicability of CLT results in many challenges to the teachers to implement CLT activities in their classrooms especially in the classrooms where English is taught as a second or a foreign language.

Furthermore, Implication of an approach like CLT requires extensive amount of classroom researches, particularly through classroom observation of teachers' practices of CLT.

First of all, teachers need to be introduced to the approach and provided with sufficient training on how to implement the approach in their classrooms, as well as make use of theory and textbooks to improve Communicative Competence of the learners. . English language teachers' instructional decisions and classroom practices are shaped by their education experience and professional development of these teachers will ultimately benefit the learners and can impact classroom practices including their choice of language teaching methodology. 


\section{STATEMENT OF PROBLEM}

The lack of communicative competence among Iraqi students may be related to the unsuccessful implementation of CLT by teachers in English language classes in Iraq. This is due to the practice of teacher dominated methods as in many Middle Eastern countries. The study by [25] on Iraqi classrooms shows that despite adopting CLT approach in the English language textbooks, English language classrooms are teacher-centered and Iraqi English language teachers cannot apply the student-centered approach.

[26] confirm the fact that Traditional teaching methods are widely used with teacher-centered education that prolongs the passive learning and impedes Iraqi language learners from attaining skills to take responsibility for their own learning and to monitor or evaluate themselves. A part of this problem is related to the English language program. [27] also indicate that the program is not completely communicative; it is a mixture of grammar-translation method, audio-lingual method and communicative approach techniques.

Furthermore, the examination-oriented teaching at schools is one of several reasons for unsuccessful implementation of CLT and practicing the teacher centered teaching method in Iraq. This was the case before introducing CLT to English language classrooms. [28] explain that teachers used to pay more attention of teaching Grammar at the expense of other skills and only for the sake of obtaining well grades and pass the exams. This seems to be related to other issues such as teachers attempt to adapt their teaching method with the current teaching and learning environment.

In his study, [29] comes to a conclusion that most of the Iraqi teachers are traditionally preoccupied with dominant sense of grammatical accuracy rather than development of ideas. This emphasis on the teaching of grammar [28] may be related to the teachers' little experience and lack of sufficient knowledge on teaching methods. All these researches above have one thing in common which is that the issue is not only with CLT itself but also the context that adopts it.

The classroom interaction which is a significant feature of communicative approach is neglected in Iraqi classrooms. This can reflect in the activities where classrooms in Iraq have failed to achieve that goal. As we see in the results of the study of [30]Alkhateeb 'Many of the activities are repetitive, failed to neither encourage truly meaningful practice, to promote realistic discourse, nor lead to the internalization of language". This means there is less use of English in classrooms and less group-work and pair works due to the large number of students. This issue requires researchers to conduct more classroom observation of English language teachers and compare these practices with the principles of CLT and the data from these observations can be used with other sources to show a clearer picture of the problem.

Many of the studies on Iraqi in-service teachers indicate that the lack of CLT training is one of the factors that tackle English language teachers from implementing CLT in their classroom. [31]'s report on the current situation in Iraq indicates that CLT is new to the teachers practice and not only teachers but also supervisors need to be made well aware of CLT through training and the current training is insufficient [25], or are mostly on the knowledge of the subject content.
The current situation of English language teaching in Iraq requires conducting researches on the adopted approach and its implementation in the classrooms. This research takes all above reasons into account in studying English language teachers' practices of CLT. It also examines the challenges that English language teachers face due to the current educational issues and factors that influence CLT practices. Since CLT is new to Iraqi context and teachers, it requires many researches to promote better teaching and learning condition in Iraq. The purpose of this research is to fill the gap in the past studies. Few of the studies tried to carry out classroom observation to describe CLT implementation in Iraqi classrooms. This study also explores teachers' knowledge on CLT principles and their opinions about the factors that hinder CLT implementation in their classrooms.

\section{RESEARCH QUESTION}

The question that this research addresses is:

To what extent the classroom practices of Iraqi English language teachers comply with the principles of Communicative Language Teaching?

\section{V.METHODOLOGY}

This study will employ a qualitative approach using classroom observation of Iraqi English language teachers using a checklist taken from [32]. The authors use this approach because through a qualitative approach the authors will be able to attain a clearer picture of the classroom reality and a better understanding of the issue of the study. the distinctive feature of observation as a research process is that it offers an investigator the opportunity to gather 'live' data from naturally occurring social situations [33]. It provides reality check that focus on behaviours or qualities of the participants' actions. The researchers collect data directly from the situation without relying on second-hand accounts. The strength of observation is that it provides more valid or authentic data than other indirect source of data collection.

In this research, classroom observation will be used as a qualitative source of data collection on teachers' classroom practices and implementation of the basic principles of communicative language teaching. This method is chosen because it is found to be effective for exploring classroom practices of English language teachers. Classroom observation as a qualitative data collection instrument is chosen to present the real picture of the classroom practices of English language teachers and their implementation of pedagogical knowledge and beliefs on Communicative Approach of language teaching.

The participants of this study are in-service Iraqi English language teachers who teach English as a foreign language. Classroom observations are conducted on 3 teachers who teach English as a foreign language for more than three years. For this purpose the researchers used a purposive sampling technique. After obtaining their consents an observation checklist was used to collect data from these teachers and the

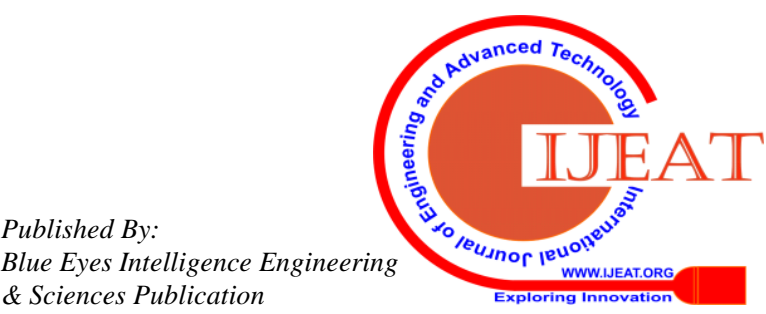


classroom will be video recorded. The observation checklist mainly investigates CLT implementation from three main criteria, teacher role, activities and materials, and teaching process. This approach will help the researchers to examine teachers' compliance to the basic principles and characteristics of Communicative language teaching that the new syllabus is based on.

\section{ANALYSIS AND RESULTS}

The data collected for this study is from classroom observations of the three teachers and from their actual teaching practices. The observations were video recorded by one of the researchers and according to the observation checklist they were descriptively analyzed, based on the three criteria provided in the checklist. The following is the details of the classroom observations and the discussion of the results.

\section{A. Data Presentation and Analysis}

\section{Observation 1:}

The first observation is of class 10 students on a lesson called ' FAMILY HEROES FIGHT HOUSE FIRE'. It is a newspaper article in the student textbook. The class starts when the teacher enters the classroom and greets the students in the first language and students answer using their first language. The researcher video tapes the lesson and during the videotape sometimes the researcher moves to different angles in the classroom to capture both the students and the teacher's actions.

The classroom consists of three rows of students where two students sit beside each. The total number of students is 32 students. The teacher asks the students to open their textbook and explains that the subject is about a newspaper article on a fire incident. The teacher stands in front of the class until she finishes reading and translating the whole text. She starts to read the text and orally translate the text line by line to Kurdish which is student's first language. During the translation the teacher sometimes asks a student to translate a line and the student stands up and gives the meaning of the line loudly. When the student finishes translating, the line the teacher repeats the translation. During the reading the teachers frequently asks the question " then what happens?" in Kurdish and she herself answer the question. When the students finish the translation of the lines the teacher replies ", ok" and " very good". While the teacher reads the text many of the students raise their hands to participate in the activity but the teacher ignores them and only choses certain students when she wants them to participate.

The students on the other hand are busy reading the text to catch up with teachers reading and translation. Some of the students did not bring the textbook and do not participate in any kind of the activities. These students seem unaware of the story that the teachers reads and avoid participation in translation. When the teacher finishes translation she asks the students to read a paragraph of the text in the student textbook. During this process the teacher moves between the rows and listen to the students who start reading loudly.

The teacher interrupts the students when they make spelling mistakes and directly corrects them. When student have difficulty reading a word the teacher reads the word loudly.
When a student finishes a paragraph the teacher signals the beginning of another paragraph by reading the first words so that the next student read it. Even though the classroom is quiet but due to the large number of students many of them do not have the chance to participate in the activities. In one particular situation when a student gives the right translation of the text the teacher rewards him by " thank you very much". When the whole text is read by some students the teacher addresses to the whole classroom and asks them to explain in their first language what the story talks about. A student stands up and briefly explains the core of the story. The teacher asks students few more questions about the story in the text to understand the story. In this point it seems that the whole class have an idea what is the story about.

After that the teacher asks a question about the reflexive pronoun and asks the students to give her an example of reflexive pronoun within the text. A student gives an example "' himself" and the teacher explains the relationship between ' 'him', and ''himself' in Kurdish language. In the textbook there is some grammatical explanation about the use and difference between past simple and past continues. The teacher asks the students to give an example of past continues in the text. A student gives example of " she was helping him". In this point the teacher explains the rules of making a past continues sentence (subject+ was/were+ verb+ing + complement) and later again asks the students to explain past continuous rule orally. The teacher moves to the white board and writes down the grammatical rule of this tense. The teacher again asks a question of the difference between using 'was' and 'were' with difference pronouns.

The teacher ends the lesson by asking "who has a question?', ' who did not understand?'” and the class are all in silence and she explains that for the next lesson they are going to answer few questions in the textbook regarding the reading text.

\section{Observation 2:}

The second observation is in a class 11 and it is a short lesson that is mostly Grammar exercises on a previous lesson. The topic is about presenting a problem and suggesting a solution for the problem. The classroom arrangement of this classroom is similar to the first observation and the only difference is that this class consists of both male and female students and the female students mostly sit in the front rows.

At the beginning of the lesson the teacher asks the students to open the activity book in page 11 and explains the purpose of the exercise and reads the exercise loudly in front of the class. The exercise consists of two rows of examples representing two people who have a dialogue together. In the first row some problems are presented by the first character (Jack) for example "' I have got problem with my phone"' and on the other side some solutions are suggested by (Tina) such as " you'd better go to a phone shop. Below this section spaces are given to write down the dialogue of the two people using the examples above. 
The teachers used Kurdish language to explain the exercise and ask the students to answer the questions. This activity is supposed to be carried out in pairs but when the teacher chose a student to carry out the activity the student suggests the problem and the solution at the same time. This happens while in the exercise there are two people who are supposed to take the roles. When each student answers, the teacher writes the answer on the white board. A female student asks a question about examination " will you give us the answer?" and the teachers answers her " yes, if give the answer when the test is multiple choice and if not you need to give suitable solution for the given problem".

When another male student tries to answer a question the teacher corrects him and translates the answer in Kurdish. When a student have difficulty understanding the meaning of ' wallet' when tries to suggest a solution for a problem . The teacher explains the meaning in Kurdish and in fact all the time during the activity the teacher used Kurdish for explanation and translation of the sentences and barely uses English for that purpose. After finishing this exercise some students again ask about examination on the subject and the teacher explains to them that during the examination either it will be multiple choice tests or a fill in blanks test. Another student asks whether the examples in the exam will be the same in the exercise or examples outside the textbook will be included. The teacher answers that the examples will be only within the given ones in the textbook or the exercise.

After this exercise the teacher asks the students to the next page (skipping two exercises in the activity book). This exercise is on vocabulary. She explains the purpose of the exercise (verb-noun pairs) and asks the students to give the noun or the verb of the given word. She also gives the meaning of each word in Kurdish, with that explaining the difference between the name and the verb in Kurdish. Except the given examples in the exercise, no further external examples is asked. At the end of the lesson the teacher asks if anyone has a question on the topic and one student asks a question about the content of the examination and she explains to her.

\section{Observation 3:}

The third observation was in a classroom of grade 12 which is the last year in high school. The number of students in this classroom was 18 male students. After greeting his students, the teacher started the lesson by orally reviewing the previous lesson and asking the classroom a general question about the previous lesson. The question was asked in English and at the same time asked in their first language (Kurdish).

After that the teacher wrote some notes on the whiteboard and told the students that today he is going to talk about possibilities and certainty in both present and past. At first the teachers asked the students to give him synonyms for both words, later he presented the rules of making possibility and certainty by writing it down on the whiteboard < Subject+ may/might/could+not/ be (verb+ing/ noun/ Adjective/ adverb)>. The teacher also asked students a question on how they recognise a sentence in present or past and when students give right answers he praised them by saying 'thank you' or "'well done".

The teacher explained the rules by giving few examples and also asked students to give him some extra examples of their own choice. Within explanation of these two language functions the teachers explained some spelling and pronunciation points about certain words that students might encounter in the final exams. As well as the teacher asked the meaning of some words and students gave either English or Kurdish meaning of the words. At the end of each topic the teacher told the students about how this topic will be asked in the final exams and he illustrated that by giving some (multiple choice / choose the right answer) examples. Three students asked questions about the topic and the teacher answered all their questions. Most questions of the teacher was addressed to the whole class and what is noted that despite the fact that the classroom was not over crowded but many students either did not want to participate in answering the teachers questions or the teacher did not ask them to participate. The lesson took 35 minutes and due to time limit the teacher could not conclude the lesson or give them certain activities or assessments.

\section{B. Discussion and results}

In this section the research shows the results and the findings of the three lessons observed and analysed. The results and discussions will concentrate on the three main aspects of CLT as explained in the observation checklist which are: materials and activities, the teacher's and students' role, and the teaching and learning process.

\section{1) Materials and Activities}

In CLT both choosing and using materials are important, especially in improving communication and student engagement in the activities. This criterion is important and many researchers put emphasis on this practice. [2] argue that " the most salient feature of CLT is that everything is done in classroom is done with a communicative purpose." The teachers in the three observations might be aware of this but the observations show that the teachers use only the prescribed textbooks the whiteboards in their classrooms. The textbooks that are called "Sunrise" are designed by Macmillan Publisher in collaboration with Ministry of Education in Kurdistan Region. Despite the claim of the publisher of adopting communicative approach in the textbooks but many studies criticize the content and methodology of the textbooks. [25] and [34] indicate that "sunrise", program is not effective and fails to meet Kurdish learners' needs. The students cannot use English outside the classrooms and the teachers in the observation rely only on the textbooks to use certain language elements such as grammar and vocabulary. In the first observation we can see that the text is from a newspaper which is an example of authentic materials and this complies with the principles of CLT. The issue of teachers is how to use these examples in the textbook and link it to real life situations through questions as strategies to use the language outside the textbook and simulate real life situations. In the third observation the teacher is supposed to teach language functions but mostly

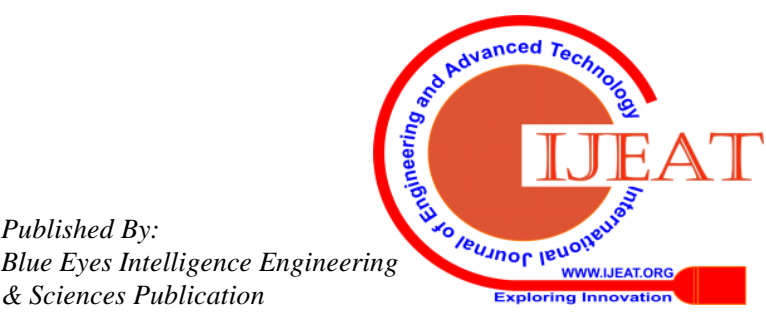


concentrate on the grammatical form of these functions due to grammar based exams rather than teaching them for the use of real life situations. The reason could be that teachers are under pressure to finish the syllabus and have not been prepared or provided with practical guidelines to teach communicatively.

One important feature that CLT promotes is the use of pair work and group works. This kind of activities can engage the students in the various activities and give them more freedom to use the language in the classroom. none of the teachers use pair work or group works even when the textbooks prescribes that in their activities as in the case of the second observation where the students have to answer the questions in pairs.

[17] indicate that activities that are truly communicative have three features in common; information - gap, choice and feedback. Information gap is when one side of the communication does know about something and the other shares the information with it through communication. In this case the students have choice to use different forms to express the same function they intend to convey in their communication. On the other side the students give feedback to each other and this way learning takes place. The students in both observations had very few chances to use information gap and knowledge sharing. Their activities were controlled by the teacher and they did not have other choices for their answers.

\section{1) Teachers' and Students' role in the classroom}

The teachers' role in their classrooms can define the methodology they practice and the activities they provide for the students. The proponents of CLT such as [17] describe the role of teachers mainly as facilitators and co-communicators. In taking this role the main responsibility of the teachers is to establish situations that promote communication. The teachers in the observation did not take that role and despite using some techniques such as question and answer but they did not establish any real situation for the students to communicate and use English sufficiently in the classroom. The teachers stuck to the activities provided by the textbooks and did not bring in any examples or situations that reflect the world outside the classroom.

According to CLT, during their activities the teachers can work as advisors by answering student questions and provide insights about the issues that obstruct in communication. Teachers in this study acted as advisors but only when students asked direct questions about the nature of examinations. They did not use any king of group activities that bring up questions and raise issues that require teachers' advice and cooperation. In this regards the teachers could not act as advisors during the classroom activities and this principle of CLT.

In CLT, the role of the teachers is less dominant, comparing to other methods. But the teachers in this study observed to be a dominantly controllers of the classroom activities which made the classroom seem more teacher-centered. The teachers provided controlled activates where students have to only a correct answer with no choices. Almost all the time the teachers stand in front of the class and did not divide the students into groups of pairs to participate in activities or solve learning problems.
The teacher interacted less with the students due to limited communication in English and the students mostly use their native language to answer teachers' questions. Most students in the classrooms observed did not participate in the activities due to possibly the nature of the activities and teachers' motivation. Thus, some students were seen to be inactive members in the classrooms. When the students make mistakes the teachers in the first and the second observations interrupted them and corrected them. Teachers' focus was mostly on the vocabulary and grammar points which indicate that both teachers focus on form rather than function and fluency of the learners language.

\section{1) Teaching and learning process}

Communicative language teaching is characterized by many principles and techniques regarding the teaching and learning language process. It focused on the student-centeredness in the classroom and task oriented teaching practices. This means the teacher's role is not dominant and students use variety of tasks to involve in communication. As a result of this the students become more responsible of their learning.

The teachers in the observations mostly followed the textbooks and did not create situations that promote communication in their classrooms. They did not encourage their students to participate in different activities and their activities were controlled. The lessons were presented in lecture form and activities were only limited in exercises and texts in the textbooks. No other materials were used to trigger communication among students.

Interaction is a salient feature of CLT classrooms and through interactions learning can take place more effectively. Interaction among learners can result in information gap activities and students take part in their learning process. In the observed lessons the teachers did not have enough interaction with the students and did not use pedagogical strategies to promote interaction among them. An example of that is when students asked questions the teachers only themselves answered the questions and no other students were involved.

Communicative language teaching promotes the use of the target language in the classroom and the target language should be considered as a medium of communication in the classroom. Freedom of using learners' first language is allowed in certain situations such as explanation or translation but in the case of these observations the teachers almost all the time use Kurdish and barely use English. Learners need to be exposed to a huge amount of spoken and heard English conversations. This helps them to gain confidence and overcome many difficulties in their attempt to learn and use English. The overuse of Kurdish in the classroom and direct translation of the texts and words from English to Kurdish is main feature of grammar translation method and teachers are advised not to practice such a method.

According to [2] language should emphasis functions over forms. This means that communication can take place by

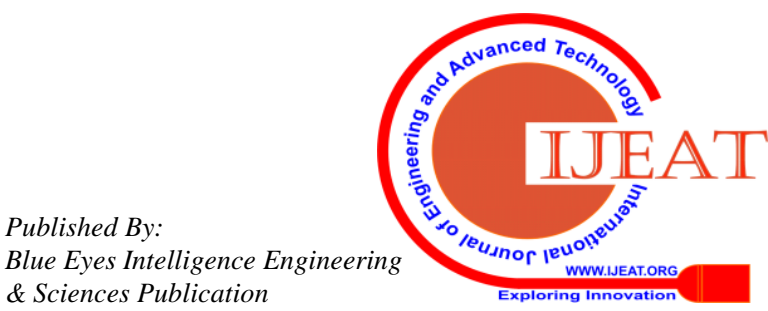


using different forms of language such as grammatical structure and vocabularies. CLT is described as a functional syllabus that aims to make communication in the target language the goal. All teachers in the observations focused either on reading activities, vocabulary or grammatical points. Less emphasis was given to communication and use of different functions. The vocabulary in the lessons was explained in Kurdish and barely English was used for explanations.

\section{CONCLUSION}

As presented earlier many studies have investigated the practice of CLT and the challenges that teachers face in different contexts but there is no research in Iraq, concerning in-service teachers' practice of CLT and their match or mismatch of their teaching practices with the principles and characteristics of CLT while implementing this approach in their teaching process. Hence, the goal of this research is to fill the gap that the researcher believes it exists in the current teaching-learning situation in Iraqi schools. For this reason, this research is dedicated to investigate the in-service teachers' practice of CLT approach.

The observation of the three lessons can provide very useful details on the actual implementation of the communicative Approach in Iraqi English language classrooms and the findings of these observations show that teachers do not fully implement CLT and their lessons are yet to be considered teacher dominated classrooms. In Iraqi classrooms class size is an issue for teachers that hinder the student participation in the activities. Reducing class size and training teachers on certain strategies to improve their teaching practice can contribute in improving communicative competence of their learners.

The findings of this study are useful to provide suggestions to in-service teachers to make more informed decisions on applying CLT in the classroom and avoid the traditional teaching method in their teaching practice. This will raise in-service teachers' awareness on the effect of CLT in their pedagogical decisions to reflect on their teaching. Hence, investigating CLT practice seems necessary for informing useful ways to educate future teachers with the advantages of the CLT approach. Iraqi in-service teachers will be more aware of the benefits of CLT and will likely implement it in their classrooms. As a consequence of this process their students will reach the expected level of communicative competence in English language.

This study is also significant because it helps the stakeholders like curriculum designers, teacher trainers, supervisors and school managers to be aware of the issues and hardship that language teachers face in the public schools and the findings of this research can give them an insight to provide a suitable guideline for the teachers in the form of instructional training regarding CLT and help them to provide basis for a more communicative environment in the schools. The last and not the least, the findings of this research will guide researchers to investigate and carry further studies on some of the CLT related issues on the educational system or school level.

\section{REFERENCES}

1. Nunan, D., Communicative tasks and the language curriculum. TESOL quarterly, 1991. 25(2): p. 279-295.

2. Richards, J.C. and T.S. Rodgers, Approaches and methods in language teaching (Cambridge language teaching library). Cambridge University, Cambridge, 2001.

3. Savignon, S.J., Communicative language teaching: Linguistic theory and classroom practice. Interpreting communicative language teaching: Contexts and concerns in teacher education, 2002: p. 1-27.

4. Kumaravadivelu, B., Beyond methods: Macrostrategies for language teaching. 2003: Yale University Press.

5. Prabhu, N.S., There is no best method-why? Tesol quarterly, 1990. 24(2): p. 161-176.

6. Richards, J.C. and C. Lockhart, Reflective teaching in second language classrooms. 1994: Cambridge University Press.

7. Galton, M., Integrating theory and practice: Teachers perspectives on educational research. 2003.

8. Wrenn, J. and B. Wrenn, Enhancing learning by integrating theory and practice. International Journal of Teaching and learning in higher education, 2009. 21(2): p. 258-265.

9. Richards, J.C., Key issues in language teaching. 2015: Cambridge University Press.

10. Bax, S., The end of CLT: A context approach to language teaching. ELT journal, 2003. 57(3): p. 278-287.

11. Nunan, D., Practical English language teaching. 2003: McGraw-Hill/Contemporary.

12. Dörnyei, Z., The 2010s. Communicative Language Teaching in the 21st Century: The "Principled Communicative Approach". Perspectives, 2009. 36(2): p. 33-43.

13. Nunan, D., Communicative Language Teaching: The Learner's View. 1986.

14. Richards, J.C. and W.A. Renandya, Methodology in language teaching: An anthology of current practice. 2002: Cambridge university press.

15. Al-Khafaji, R.S., AN APPLICATION OF THE COMMUNICATIVE LANGUAGE TEACHING (CLT) APPROACH FOR ENGLISH AS A FOREIGN LANGUAGE (EFL) LEARNERS IN THE ARAB CONTEXT. 2015.

16. Brown, H.D., Principles of language learning and teaching. 2000.

17. Larsen-Freeman, D., Techniques and principles in language teaching. 2000: Oxford University.

18. Richards, J.C., Developing classroom speaking activities: From theory to practice. GUIDELINES-SINGAPORE-PERIODICAL FOR CLASSROOM LANGUAGE TEACHERS THEN MAGAZINE FOR LANGUAGE TEACHERS-, 2006 28(2): p. 3 .

19. Ibrahim, M.K. and Y.A. Ibrahim, Communicative English language teaching in Egypt: Classroom practice and challenges. Issues in Educational Research, 2017. 27(2): p. 285.

20. Islam, F., Effectiveness of communicative language teaching at primary level in Bangladesh. 2016, BRAC University.

21. Hiep, P.H. Imported" communicative language teaching: Implications for local teachers. in English Teaching Forum. 2005. 
22. Syarief, K., Communicative language teaching: Exploring theoretical foundations and practical challenges. Jurnal Ilmu Pendidikan, 2016. 12(3).

23. Yusof, F.M. and H. Halim, Understanding teacher communication skills. Procedia-Social and Behavioral Sciences, 2014. 155: p. 471-476.

24. Demir, A., A. Yurtsever, and B. Çimenli, The relationship between tertiary level EFL teachers' self-efficacy and their willingness to use communicative activities in speaking. Procedia-Social and Behavioral Sciences, 2015. 199: p. 613-619.

25. Sofi-Karim, M., English language teaching in the Kurdistan Region of Iraq. 2015: Webster University.

26. Mhamad, A. and M. Shareef, Education in Kurdistan: A lost cause. Fair Observer, 2014.

27. Hassan, F.R. and O.F. Ghafor, Assessing the suitability of "sunrise" programme to the Kurdish learners of the seventh basic grade in the schools of Erbil city. Journal of Teaching and Education, 2014. 3(3): p. 469-482.

28. Saeed, N.R., Problems of Teaching English in Iraqi Public Schools in Mosul for the Intermediate Stage from the Teachers' Point of View. 2015, Middle East University.

29. AlAkeeli, F.S., Examining Lexical and Grammatical Difficulties Encountered by Iraqi Students in Learning English as a Foreign Language. 2013, St Clements University.

30. Alkhateeb, M.M.A., Evaluating Iraqi Primary EFL Curriculum and Textbooks. JPAIR Multidisciplinary Research, 2013. 12(1).

31. UNESCO, UNESCO National Education Support Strategy. 2014: UNESCO IRAQ OFFICE. p. 99.

32. Elzubier, E.A., The Communicative Language Teaching and its Dilemma in Sudanese EFL Classroom, in 3RD INTERNATIONAL LANGUAGE CONFERENCE (ILC) 2014. 2014. p. 1-27.

33. Cohen, L., L. Manion, and K. Morrison, Research methods in education. 2007, New York, NY: Routledge.

34. Ebadi, S. and I.M. Hasan, A Critical Analysis of Tasks in EFL Textbook: A Case Study of Sunrise 12. English for Specific Purposes World, 2016. 17(49).

\section{AUTHORS PROFILE}

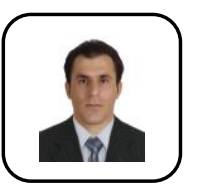

Arkhawan Fattah has got his first degree at Salahaddin University-Iraq, has done his masters at Bharati Vidyapeeth Deemed University,Pune-India and currently doing his $\mathrm{PhD}$ at Universiti Teknologi Malaysia-Malaysia. His field of research is Teaching English As a second Language. His interested fields of research are teaching English as a second and foreign language. Teacher training, Content -language Integrated learning..

Dr Aminabibi Bte Saidalvi is a lecturer at Language Academy, Faculty of Social Sciences and Humanities. She is currently the Head of the Postgraduate Study Committee and Head of Research Group (RG) of Second Language Studies. She has 25 years of experience in teaching English Language in all levels of education 